\title{
Selective Increase of NMDA-Sensitive Glutamate Binding in the Striatum of Parkinson's Disease, Alzheimer's Disease, and Mixed Parkinson's Disease/Alzheimer's Disease Patients: An Autoradiographic Study
}

\author{
Jolanta Uras,' Fredric B. Weihmuller, ${ }^{2}$ Lance C. Brunner, ${ }^{1}$ Jeffrey N. Joyce, ${ }^{3}$ John F. Marshall,, ${ }^{2}$ and Carl W. \\ Cotman' \\ IIvine Research Unit in Brain Aging and 'Department of Psychobiology, University of California, Irvine, California \\ 92717-4550, and ${ }^{3}$ Department of Psychiatry, School of Medicine, University of Pennsylvania, Philadelphia, Pennsylvania \\ 19104
}

Parkinson's disease (PD) and Alzheimer's disease (AD) may share certain abnormalities since a subset of $P D$ patients suffer from dementia, and some AD individuals show extrapyramidal symptoms. In vitro quantitative autoradiography was used to examine different subtypes of excitatory amino acid (EAA) receptors (NMDA, KA, and AMPA) and dopamine transporter sites in the striatum (caudate, putamen) and nucleus accumbens (NAc) from idiopathic PD, pure AD, and mixed PD/AD patients. PD and $A D$ groups, and to a lesser extent the PD/AD group, showed substantially increased binding to NMDA receptors in the striatum and NAC. No statistically significant changes in binding to KA and AMPA receptors were found in any patient group. ${ }^{3} \mathrm{H}$-mazindol binding to dopamine transporter sites was significantly decreased in the striatum and NAC of PD and PD/AD patients, but only in the putamen and NAC of AD patients. The data indicate that (1) the majority of striatal EAA receptors are not located on dopaminergic nigrostriatal nerve terminals, and (2) elevated binding to striatal NMDA receptors correlates with binding to dopamine transporter sites in PD patients, but not in AD and PD/AD individuals. Thus, the mechanisms of NMDA receptor changes in the striatum of $A D$ and PD patients may be different. However, it is postulated that increased binding to NMDA receptors in Parkinson and Alzheimer striatum occurs in response to an insult(s) within the striatothalamocortical circuits and that this may contribute to the clinical similarities described for subsets of PD and AD patients.

[Key words: excitatory amino acid receptor, striatum, nucleus accumbens, Parkinson's disease, Alzheimer's disease, mixed Parkinson's/A/zheimer's disease, human, autoradiography]

Recently we have postulated that a substantial elevation in binding to NMDA receptors in the striatum of Parkinson's disease (PD) patients (Weihmuller et al., 1992) may be due to dopamine

Received Feb. 1, 1994; revised Apr. 11, 1994; accepted Apr. 21, 1994.

This work was supported by NIA Grants AG07918 (LEAD Award), AG05142, AG00538 (C.W.C.), and USPHS Grant NS22698 (J.F.M.).

Correspondence should be addressed to Jolanta Uhas, Ph.D., Irvine Research Unit in Brain Aging, BioSci II, University of California, Irvine, CA 92717-4550. Copyright (C) 1994 Society for Neuroscience 0270-6474/94/146317-08\$05.00/0
(DA)-glutamate imbalances within the striatothalamocortical loop of PD brain. However, it is quite possible that such imbalances exist in other neurodegenerative diseases, for example, in Alzheimer's disease (AD), and involve other subtypes of excitatory amino acid (EAA) receptors.

Growing evidence suggests that $\mathrm{PD}$ and $\mathrm{AD}$ may share certain abnormalities at neuronal, neurochemical, and clinical levels. These include the presence of ncurofibrillary tangles and ncuritic plaques typical for AD in the brain of some PD patients (Boller et al., 1980; Jellinger et al., 1990). Conversely, some AD subjects show the presence of cortical and subcortical Lewy bodies (Hansen et al., 1990), and a loss of dopaminergic processes in the putamen (Allard et al., 1990) characteristic of PD. Moreover, a proportion of PD patients suffers from dementia (Cummings, 1986), and some AD individuals exhibit extrapyramidal symptoms (Molsa et al., 1984; Leverenz and Sumi, 1986).

The basal ganglia pathology and deficits in dopaminergic transmission in PD are well characterized (Hornykiewicz, 1973). There is, however, increasing evidence for an involvement of the glutamatergic system in PD. The striatum and substantia nigra receive an excitatory glutamatergic input from the cortex (Carter, 1982; Fonnum, 1984; Francis et al., 1993) and some glutamatergic neurons have presynaptic dopaminergic receptors that can regulate the release of glutamate (Mitchell and Doggett, 1980; Crowder and Bradford, 1987). On the other hand, L-glutamate or other EAA receptor agonists can stimulate DA release in the striatum and substantia nigra (Nieoullon et al., 1978; Cheramy et al., 1986; Carter et al., 1988; Clow and Jhamandas, 1989; Mount et al., 1990; Desce et al., 1991; Krebs et al., 1991; Westerink et al., 1992).

Other data suggest that some antiparkinsonian agents may exert their clinical effects via blockade of NMDA receptors (OIney et al., 1987; Lustig et al., 1992). In certain animal models of PD, NMDA and AMPA receptor antagonists were found to reverse parkinsonian symptoms (Klockgether et al., 1991) or potentiate the ability of L-dopa to reverse akinesia and to alleviate muscular rigidity (Klockgether and Turski, 1990), further emphasizing the importance of glutamate-DA interactions in normal striatal function and in PD.

As we reported previously, an increased NMDA receptor binding in PD striatum is accompanied by a significant decrease in the DA transporter sites (Weihmuller et al., 1992). The same study demonstrated that in elderly controls the distribution of 


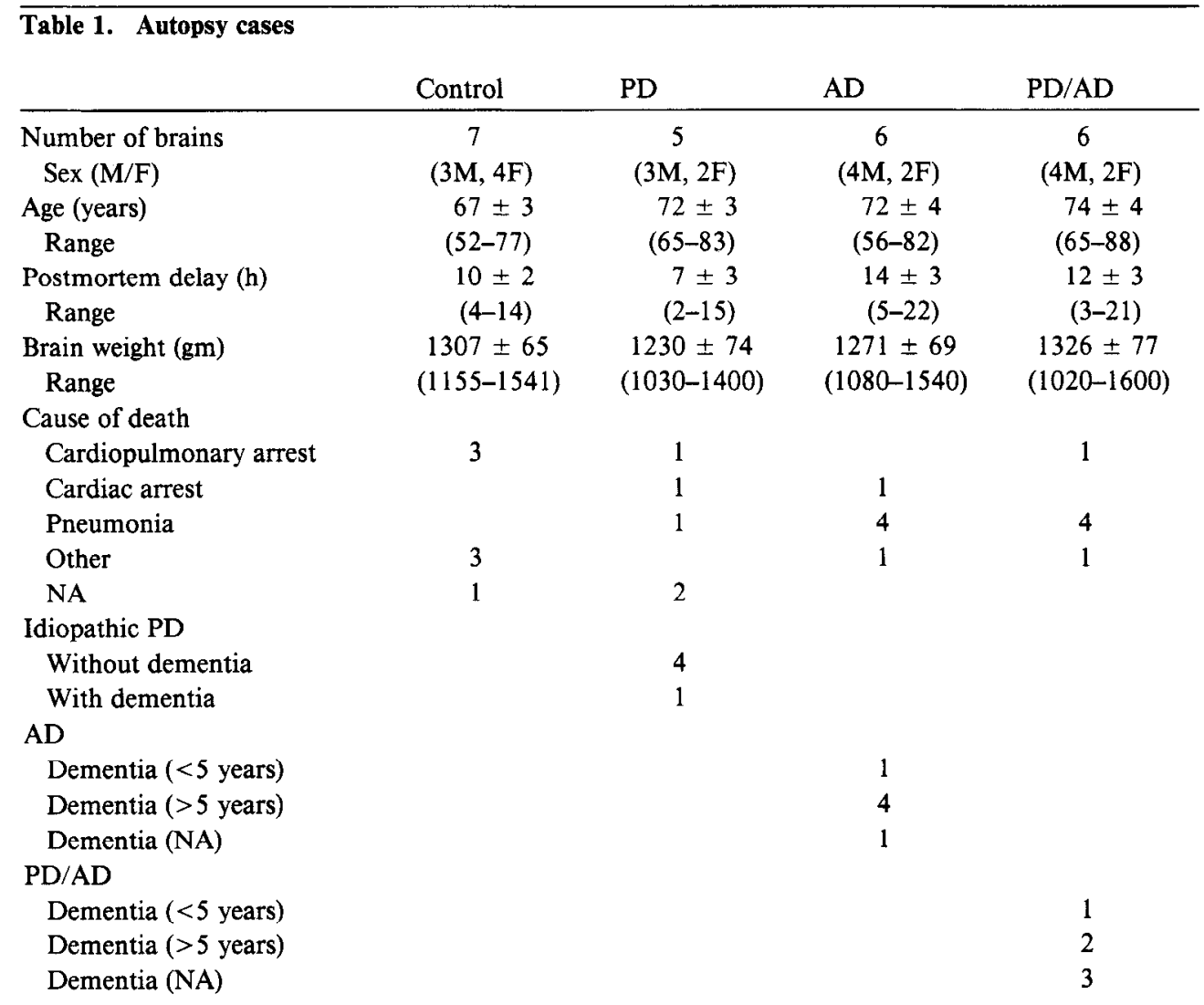

Data are shown as means \pm SEM. As explained in Materials and Methods, the division of patients into PD, AD, and PD/AD groups was based mainly on neuropathological findings. All PD patients underwent pharmacological treatment including Sinemet or L-dopa.

NMDA receptors resembles that of ${ }^{3} \mathrm{H}$-mazindol-labeled DA transporter sites in that the binding is greater in the ventral caudate and putamen relative to their dorsal regions (Weihmuller et al., 1992). Since changes in NMDA receptors may reflect altered activity of EAA-containing afferents, there is the possibility that reduced nigrostriatal DA activity may lead to modifications within corticostriatal glutamate synapses. However, despite evidence that NMDA receptors may have a role in $\mathrm{PD}$, the involvement of other subtypes of EAA receptors in DA-glutamate interactions in the basal ganglia of control and PD patients has received limited attention (Difazio et al., 1992; Penney et al., 1992). Similarly, little information is available regarding the status of EAA and DA systems in the striatum of AD and mixed PD/AD cases (Penney et al., 1992). Furthermore, the reports of unchanged binding to NMDA and KA receptors in the caudate of AD individuals (Cowburn et al., 1988, 1989; Simpson et al., 1988) seem to contradict the prediction that there are imbalances in both the glutamatergic and dopaminergic systems in AD.

Accordingly, in this study we have examined the distribution and changes of various ionotropic EAA receptors in the striatum of $\mathrm{PD}, \mathrm{AD}$ and mixed $\mathrm{PD} / \mathrm{AD}$ individuals and age-matched elderly controls. To characterize DA-glutamate interactions further, the changes in EAA receptors were compared with the integrity of nigrostriatal dopaminergic terminals.

\section{Materials and Methods}

Chemicals. Unless otherwise indicated, all chemicals were purchased from Sigma, St. Louis, MO. The radioligands L- ${ }^{3} \mathrm{H}$-glutamate, ${ }^{3} \mathrm{H}-\mathrm{kain}-$ ate $\left({ }^{3} \mathrm{H}-\mathrm{KA}\right),{ }^{3} \mathrm{H}-\alpha$-amino-3-hydroxy-5-methyl-4-isoxazolepropionic acid ( ${ }^{3} \mathrm{H}$-AMPA), and ${ }^{3} \mathrm{H}$-mazindol were purchased from New England $\mathrm{Nu}$ clear-DuPont (Boston, MA); ${ }^{3} \mathrm{H}$ standards and ${ }^{3} \mathrm{H}$-Hyperfilm, from Amersham (Arlington Heights, IL); and NMDA, KA, and AMPA, from Tocris Neuramin (Bristol, England).

Human autopsy tissue. Brains were cut in 5-7-mm-thick coronal slabs and stored at $-70^{\circ} \mathrm{C}$ prior to sectioning on a cryostat. Striatal tissue at the rostral level (head of caudate and putamen) from seven control individuals, five idiopathic PD individuals, six AD individuals, and six mixed $\mathrm{PD} / \mathrm{AD}$ subjects (Table 1) was obtained from Human Tissue Repositories at University of California, Irvine and University of Pennsylvania, Philadelphia. The final diagnosis of $A D, P D$, and mixed PD/ $A D$ was based on postmortem neuropathological findings and supported by description of clinical symptoms. Accordingly, idiopathic PD patients all demonstrated pigmentary incontinence, neuronal loss, and the presence of Lewy bodies in the substantia nigra and locus coeruleus, but not pathology indicating AD. The diagnosis of AD patients was based on neuropathological evaluation of the presence and density of neuritic plaques and neurofibrillary tangles in the various brain regions in accordance with the NIA/NINCDS criteria (Khachaturian, 1985), and the absence of other pathology to explain the dementia. AD patients did not have substantial nigral cell loss and did not show the presence of Lcwy bodies in the substantia nigra, locus ceruleus and cortex. Mixed $\mathrm{PD} / \mathrm{AD}$ individuals all showed $\mathrm{PD}$ pathology but also had pathologic evidence of AD and exhibited to different degrees clinical symptoms of each disease.

Control individuals analyzed in the present study had no history of psychiatric or neurologic disease and no history of alcoholism or drug abuse, and upon postmortem, neuropathological examination showed no diagnostic change.

The patients from the control, $\mathrm{PD}, \mathrm{AD}$, and $\mathrm{PD} / \mathrm{AD}$ groups were matched according to age, sex, and postmortem interval (Table 1).

Autoradiography. Serial brain sections ( $20 \mu \mathrm{m}$ thick) were cut using a cryostat, thaw mounted onto gelatin chrom-alum-subbed slides, and stored at $-70^{\circ} \mathrm{C}$ until used. Receptor binding assays were performed 
Table 2. EAA receptor and dopamine transporter binding assays

\begin{tabular}{|c|c|c|c|c|c|}
\hline Assay & Ligand & $\begin{array}{l}\text { Specific } \\
\text { activity and } \\
\text { concentration }\end{array}$ & Incubation & Blockers & Nonspecific \\
\hline NMDA receptor & L- ${ }^{3} \mathrm{H}$-glutamate & $49 \mathrm{Ci} / \mathrm{mmol}, 200 \mathrm{nM}$ & $\begin{array}{c}50 \mathrm{~mm} \text { Tris-acetate, } \mathrm{pH} \\
7.0,10 \mathrm{~min} \text { at } 0-4^{\circ} \mathrm{C}\end{array}$ & $\begin{array}{c}1 \mu \mathrm{M} \mathrm{KA}, 5 \mu \mathrm{M} \text { AMPA, } \\
100 \mu \mathrm{M} \text { SITS }\end{array}$ & $200 \mu \mathrm{M}$ NMDA \\
\hline KA receptor & ${ }^{3} \mathrm{H}-\mathrm{KA}$ & $58 \mathrm{Ci} / \mathrm{mmol}, 50 \mathrm{nM}$ & $\begin{array}{r}50 \mathrm{~mm} \text { Tris-citrate, } \mathrm{pH} \\
7.0,30 \mathrm{~min} \text { at } 0-4^{\circ} \mathrm{C}\end{array}$ & & $100 \mu \mathrm{M} \mathrm{KA}$ \\
\hline AMPA receptor & ${ }^{3} \mathrm{H}$-AMPA & $60 \mathrm{Ci} / \mathrm{mmol}, 50 \mathrm{nM}$ & $\begin{array}{c}50 \mathrm{~mm} \text { Tris-acetate, } \mathrm{pH} \\
7.2,10 \mathrm{~min} \text { at } 0-4^{\circ} \mathrm{C}\end{array}$ & & $100 \mu \mathrm{M}$ AMPA \\
\hline DA transporter & ${ }^{3} \mathrm{H}$-mazindol & $15-30 \mathrm{Ci} / \mathrm{mmol}, 15 \mathrm{nM}$ & $\begin{array}{l}50 \mathrm{~mm} \text { Tris, } 300 \mathrm{~mm} \\
\mathrm{NaCl}, 5 \mathrm{~mm} \mathrm{KCl}, \mathrm{pH} \\
7.9,40 \mathrm{~min} \text { at } 0-4^{\circ} \mathrm{C}\end{array}$ & $\begin{array}{l}0.3 \mu \mathrm{M} \text { desmethylimi- } \\
\text { pramine } \cdot \mathrm{HCl}\end{array}$ & $\begin{array}{l}30 \mu \mathrm{M} \text { benztropine } \\
\text { methanesulfonate }\end{array}$ \\
\hline
\end{tabular}

on tissue from control, $\mathrm{PD}, \mathrm{AD}$, and $\mathrm{PD} / \mathrm{AD}$ groups at the same time to avoid differences in binding assay conditions.

$E A A$ receptors. Binding to NMDA, KA, and AMPA receptors was performed as previously described (Geddes et al., 1992; Ulas et al., 1992; Weihmuller et al., 1992). Tissue sections were prewashed for 30 $\mathrm{min}$ in ice-cold buffer, preincubated in the same buffer for $10 \mathrm{~min}(\mathrm{KA}$, AMPA receptors) or $2 \times 10 \mathrm{~min}$ (NMDA receptor) at $30^{\circ} \mathrm{C}$, and incubated at $0-4^{\circ} \mathrm{C}$ with respective radioligand (Table 2).

DA transporter. ${ }^{3} \mathrm{H}$-mazindol labeling of the striatal DA transporter, a measure of preservation of the nigrostriatal pathway, was performed as previously described (Weihmuller et al., 1992). Briefly, after a 5 min preincubation in a $50 \mathrm{~mm}$ Tris $+300 \mathrm{~mm} \mathrm{NaCl}$ buffer with $0.3 \mu \mathrm{M}$ desmethylimipramine $\cdot \mathrm{HCl}$ (to occlude noradrenergic uptake sites), slides were incubated for $40 \mathrm{~min}$ at $0^{\circ} \mathrm{C}$ with ${ }^{3} \mathrm{H}$-mazindol (Table 2).

Following incubation, unbound radioactivity was removed by rinsing the slides in a series of baths with ice-cold buffer. Sections were then dried under a stream of cold air (EAA receptors) or on a hot plate $\left({ }^{3} \mathrm{H}\right.$ mazindol), placed along with ${ }^{3} \mathrm{H}$ standards in $\mathrm{x}$-ray cassettes, and apposed to ${ }^{3} \mathrm{H}$-sensitive film ( ${ }^{3} \mathrm{H}$-Hyperfilm) for 3 weeks (EAA receptors) or 4 weeks (DA transporter sites). Autoradiograms were analyzed by computer-assisted densitometry with an MCID image processing system (St. Catherines, Ontario, Canada). Quantification was performed in the striatum (caudate, putamen) and nucleus accumbens (NAc), and specific binding was calculated by subtracting the density of nonspecific binding from the total binding. Both the dorsal and ventral regions of caudate and putamen were analyzed. For each individual, densitometry was performed on at least two tissue sections and the average binding value from each individual was considered one observation.

Statistical analysis. Statistical analyses were conducted using analysis of variance (ANOVA) followed by Tukey post hoc tests. Regression analysis was used to determine relationship between DA transporter sites and NMDA receptors. Statistical significance was defincd as $p<$ 0.05 .

\section{Results}

Comparison of the distribution of EAA binding sites and $D A$ transporter sites in the striatum of normal, elderly individuals The binding to NMDA, KA, and AMPA receptors was measured in the caudate, putamen, and NAc of seven elderly, control individuals. As shown in Table 3, the NAc appears to be enriched in both AMPA- and NMDA-sensitive sites as compared to the caudate and putamen. In contrast, ${ }^{3} \mathrm{H}-\mathrm{KA}$ binding levels were similar throughout the striatum. In the caudate and putamen, their ventral regions demonstrated slightly higher binding to NMDA and AMPA receptors than their dorsal areas $[F(1,6)=49.04, p<0.001$, and $F(1,6)=5.8, p<0.05$, respectively].

Similarly, a greater binding to DA transporter sites was observed in the ventral caudate and putamen than their dorsal region $[F(1,6)=25.18, p<0.005$; Table 3$]$. In contrast to the distribution of EAA receptors, the binding to DA transporter sites was higher in the caudate and putamen than in the NAc, as reported previously (Weihmuller et al., 1992).

\section{$N M D A$ receptors in $P D, A D$, and mixed $P D / A D$}

As depicted in Figures 1 and $2, \mathrm{~L}^{-3} \mathrm{H}$-glutamate binding to NMDA-sensitive sites was substantially increased in the caudate, putamen, and NAc of $P D, A D$, and $P D / A D$ patients as compared to the binding in elderly controls. An overall threefactor mixed ANOVA using diagnostic group (elderly control, $\mathrm{PD}, \mathrm{AD}$, and mixed PD/AD) as a between factor, and structure (caudate vs putamen) and region (dorsal vs ventral) as withinsubjects factors disclosed significant main effects of diagnostic group $[F(3,20)=3.08, p<0.05]$ and region $[F(1,20)=83.64$, $p<0.001]$ but not of structure. Tukey post hoc analyses showed that $\mathrm{PD}, \mathrm{AD}$, and $\mathrm{PD} / \mathrm{AD}$ groups all had greater $\mathrm{L}^{-}{ }^{3} \mathrm{H}$-glutamate binding to striatal NMDA receptors than elderly controls $(p<$ $0.05)$.

In PD patients this increase reached $32 \%$ and $28 \%$ in the dorsal and ventral caudate, respectively, and $46 \%$ and $35 \%$ in the dorsal and ventral putamen, respectively (all $p<0.05$; Fig. 1). In AD striatum, the binding was elevated by $33 \%(p<0.05)$

Table 3. The distribution of binding to EAA receptors and DA transporter sites in the striatum of normal, elderly individuals

\begin{tabular}{|c|c|c|c|c|c|}
\hline \multirow[b]{2}{*}{${ }^{3} \mathrm{H}$-ligand } & \multicolumn{2}{|l|}{ Caudate } & \multicolumn{2}{|l|}{ Putamen } & \multirow{2}{*}{$\begin{array}{l}\text { Nucleus } \\
\text { accumbens }\end{array}$} \\
\hline & Dorsal & Ventral & Dorsal & Ventral & \\
\hline L-Glutamate & $369 \pm 33$ & $446 \pm 43$ & $370 \pm 25$ & $437 \pm 32$ & $490 \pm 42$ \\
\hline $\mathrm{KA}$ & $444 \pm 20$ & $436 \pm 28$ & $449 \pm 22$ & $428 \pm 18$ & $430 \pm 27$ \\
\hline AMPA & $698 \pm 61$ & $723 \pm 53$ & $707 \pm 61$ & $755 \pm 65$ & $948 \pm 74$ \\
\hline Mazindol & $1396 \pm 160$ & $1645 \pm 176$ & $1417 \pm 219$ & $1686 \pm 265$ & $1239 \pm 53$ \\
\hline
\end{tabular}

Data are expressed in fmol/mg protein and represent means \pm SEM from seven individuals. 

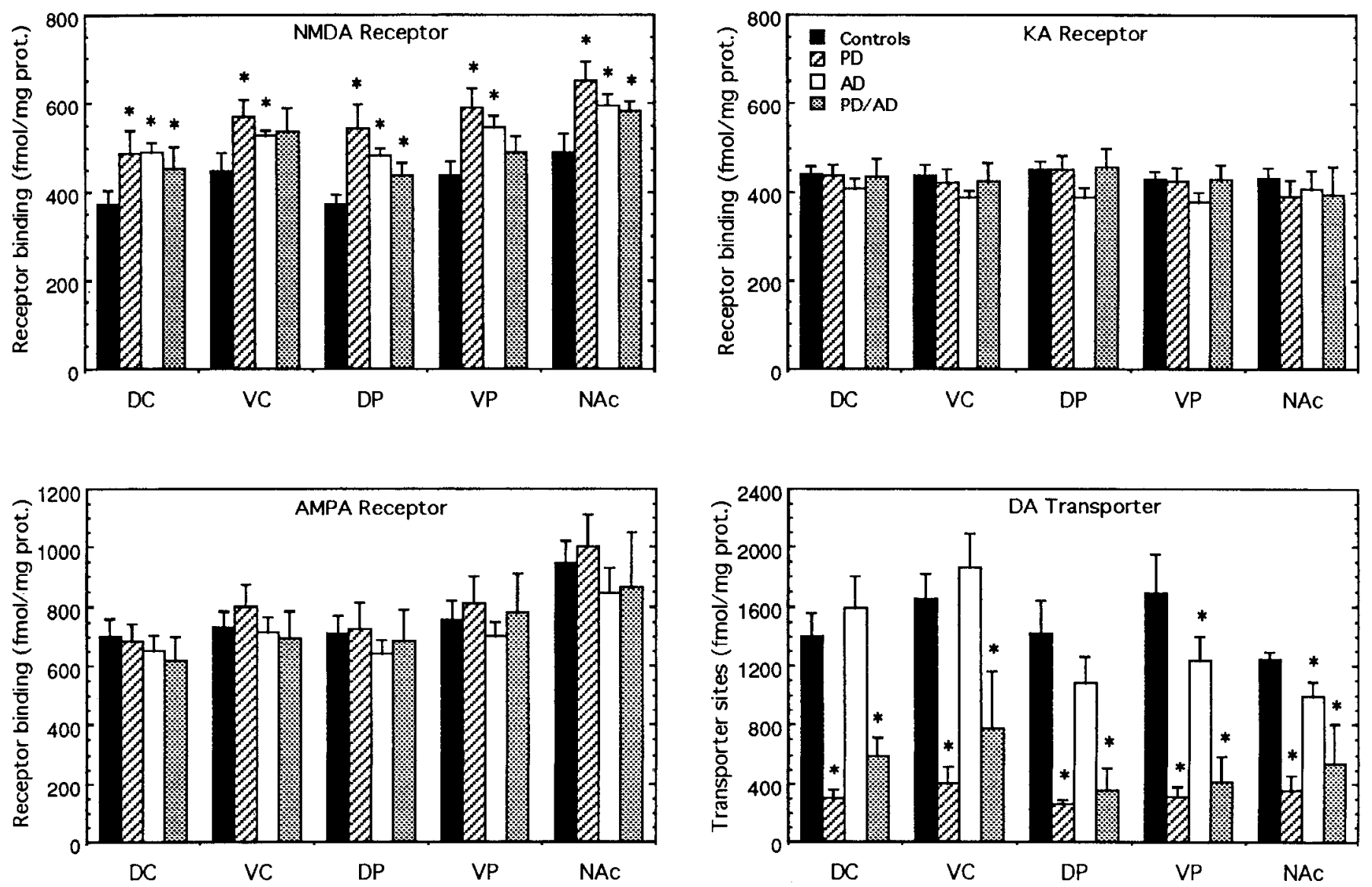

Figure 1. Quantification of $\mathrm{L}^{-}{ }^{3} \mathrm{H}$-glutamate, ${ }^{3} \mathrm{H}-\mathrm{KA},{ }^{3} \mathrm{H}-\mathrm{AMPA}$, and ${ }^{3} \mathrm{H}$-mazindol binding to NMDA, KA, and AMPA receptors, and DA transporter sites in the various structures and regions of PD, AD, and mixed PD/AD striatum, and nucleus accumbens. Data represent means \pm SEM from five $\mathrm{PD}$, six $\mathrm{AD}$, and six $\mathrm{PD} / \mathrm{AD}$ individuals. $D C$, dorsal caudate; $V C$, ventral caudate; $D P$, dorsal putamen; $V P$, ventral putamen; $N A C$, nucleus accumbens. ${ }^{*}, p<0.05$ as compared to controls.

in the dorsal caudate and $18 \%$ in the ventral caudate, $31 \%(p$ $<0.05)$ in the dorsal putamen, and $25 \%(p<0.05)$ in the ventral putamen. In the population of mixed $\mathrm{PD} / \mathrm{AD}$ patients, the elevation of binding to NMDA receptors was smaller. In dorsal caudate the binding increased by $23 \%(p<0.05)$, in the dorsal putamen by $18 \%(p<0.05)$, whereas the increase of binding in the ventral caudate $(20 \%)$ and ventral putamen $(12 \%)$ did not reach statistical significance. Moreover, in all diagnostic groups the ventral caudate and putamen each exhibited higher levels of $\mathrm{L}^{-3} \mathrm{H}$-glutamate binding than the dorsal region of these nuclei $(p<0.05)$.

A single-factor (diagnostic group) ANOVA performed on $\mathrm{L}^{-3} \mathrm{H}-$ glutamate binding to NMDA-sensitive sites in the NAc indicated significant differences in NMDA receptor levels between the different diagnostic groups $[F(3,14)=3.38, p<0.05]$. In comparison with elderly controls, the binding was elevated by $33 \%$ in PD patients, $21 \%$ in AD patients, and $19 \%$ in mixed PD/AD patients (all $p<0.05$ ).

\section{$K A$ receptors in $P D, A D$, and mixed $P D / A D$}

In contrast to NMDA receptors, binding to $\mathrm{KA}$ receptors in the striatum of $\mathrm{PD}, \mathrm{AD}$, and $\mathrm{PD} / \mathrm{AD}$ patients was unchanged as compared to elderly controls (Figs. 1,2). A three-factor mixed ANOVA using diagnostic group (elderly control, PD, AD, and $\mathrm{PD} / \mathrm{AD}$ ) as a between factor, and structure (caudate vs putamen) and region (dorsal vs ventral) as within-subjects factors revealed a significant main effect of region $[F(1,20)=8.64, p<0.01]$ but no main effects of either diagnostic group or structure. However, a trend toward slightly $\left(8-14 \%\right.$, NS) diminished ${ }^{3} \mathrm{H}-\mathrm{KA}$ binding was found in the caudate and putamen of AD patients. Tukey post hoc analyses of the region effect indicated that, when all diagnostic groups were included, the dorsal region of the caudate and putamen had slightly higher binding levels to KA receptors than the ventral region of these structures $(p<0.05)$. This effect appears to occur because of slightly diminished KA binding in $\mathrm{AD}$ individuals. No significant interaction effects between these factors were found.

A single-factor ANOVA comparing KA receptor binding in the NAc amongst the different diagnostic groups showed no significant differences between these subject groups.

\section{$A M P A$ receptors in $P D, A D$, and mixed $P D / A D$}

As compared to elderly controls, no statistically significant changes in binding to AMPA sites were found in the striatum of $\mathrm{PD}, \mathrm{AD}$, and $\mathrm{PD} / \mathrm{AD}$ patients (Figs. 1, 2). An overall threefactor mixed ANOVA using diagnostic group (elderly control, $\mathrm{PD}, \mathrm{AD}$, and PD/AD) as a between factor, and structure (caudate vs putamen) and region (dorsal vs ventral) as within-subjects factors revealed a significant main cffcct of structure $[F(1,20)$ $=4.85, p<0.05]$ and region $[F(1,20)=52.67, p<0.001]$ but no diagnostic group effect. Tukey post hoc analyses indicated that the putamen had significantly greater AMPA receptor bind- 

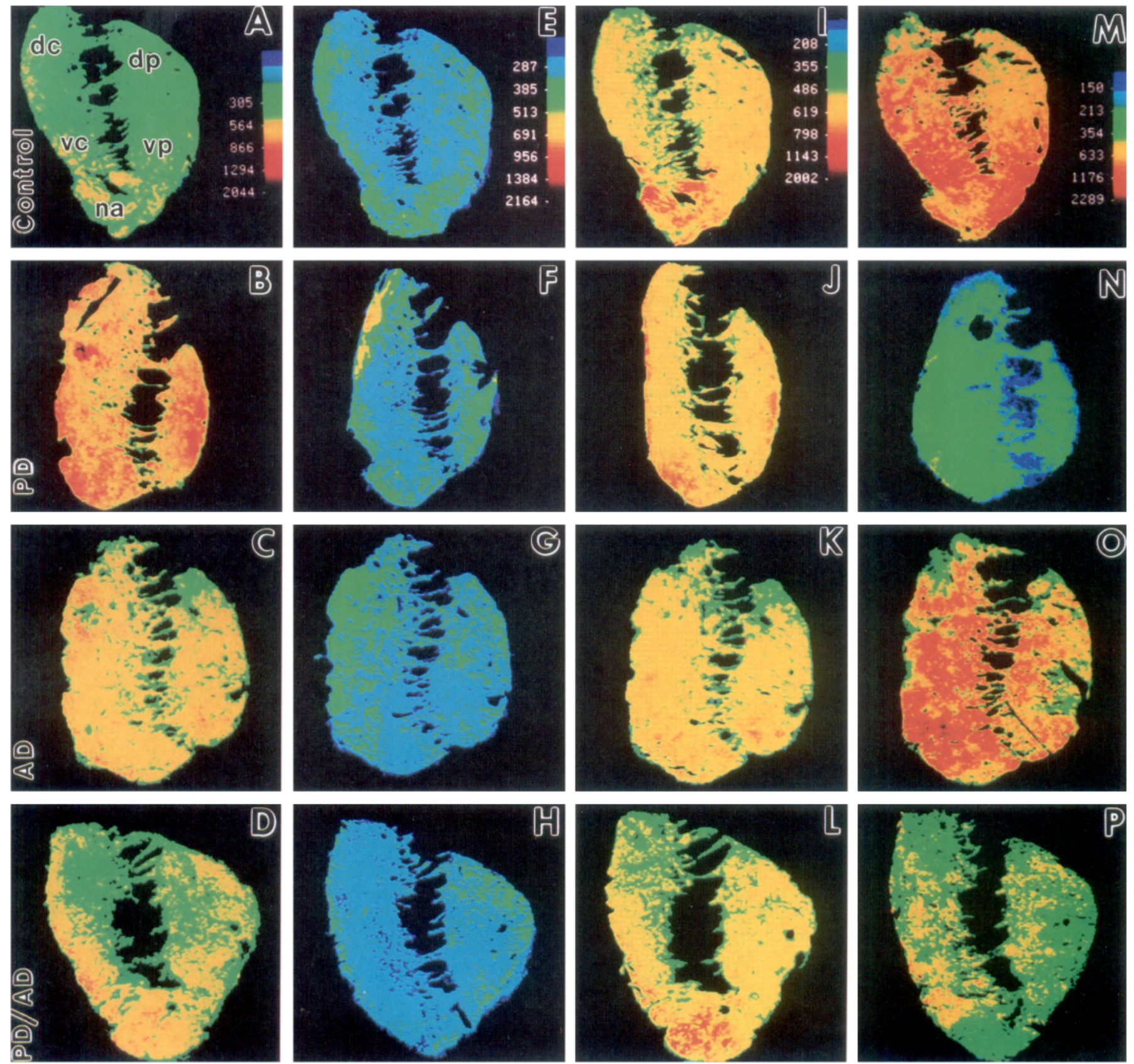

Figure 2. Pseudocolor images of $\mathrm{L}_{-}{ }^{3} \mathrm{H}$-glutamate binding to NMDA receptors $(A-D),{ }^{3} \mathrm{H}-\mathrm{KA}$ binding to KA receptors $(E-H),{ }^{3} \mathrm{H}-\mathrm{AMPA}$ binding to AMPA receptors $(I-L)$, and ${ }^{3} \mathrm{H}$-mazindol binding to DA transporter sites $(M-P)$ were generated from autoradiograms of select control, PD, AD, and mixed PD/AD striata. Note significant increase in binding to NMDA receptors in all diagnostic groups and striatal regions $(B-D)$. Note also a generalized severe decrease of binding to DA transporter sites in PD striatum $(N)$, small loss of binding in AD individuals $(O)$, and moderate loss of binding in PD/AD patients $(P)$. $d c$, dorsal caudate; $v c$, ventral caudate; $d p$, dorsal putamen; $v p$, ventral putamen; na, nucleus accumbens.

ing than the caudate $(p<0.05)$ and that the ventral region of both the caudate and putamen was enriched in AMPA binding sites as compared to the dorsal regions of these structures $(p<$ 0.05 ). No significant interaction effects were found.

A single-factor ANOVA conducted on ${ }^{3} \mathrm{H}$-AMPA binding data in the NAc showed no differences amongst elderly controls, $\mathrm{PD}, \mathrm{AD}$, and $\mathrm{PD} / \mathrm{AD}$ patients.

\section{$D A$ transporter sites in $P D, A D$ and mixed $P D / A D$ patients}

In comparison with controls, ${ }^{3} \mathrm{H}$-mazindol binding to striatal DA transporter sites was markedly decreased in PD and PD/
AD patients (Figs. 1, 2). A three-factor mixed ANOVA using diagnostic groups as a between-subject factor, and structure (caudate vs putamen) and region (dorsal vs ventral) as withinsubjects factors revealed significant main effects of diagnostic group $[F(3,20)=14.60, p<0.001]$, structure $[F(1,20)=13.34$, $p<0.001]$, and region $[F(1,20)=18.85, p<0.001]$. Tukey post hoc analyses showed that PD and mixed PD/AD subjects had fewer ${ }^{3} \mathrm{H}$-mazindol-labeled DA transporter sites than the elderly controls and $\mathrm{AD}$ patients ( $p<0.05 ; \mathrm{Fig} .1)$. Furthermore, post hoc analyses of the significant effect of structure suggested that amongst these combined diagnostic groups, the caudate 
Table 4. Relationship between binding to NMDA receptors and DA transporter sites in the caudate and putamen nuclei of elderly control, PD, AD, and mixed PD/AD individuals

\begin{tabular}{llllll} 
& Caudate & & & Putamen \\
\cline { 2 - 3 } \cline { 5 - 6 } & Dorsal & Ventral & & Dorsal & Ventral \\
\hline Control & +0.44 & +0.40 & & $+0.71^{*}$ & +0.65 \\
PD & $-0.79^{*}$ & -0.36 & & $-0.87^{*}$ & $-0.97^{*}$ \\
AD & -0.18 & +0.39 & & -0.04 & +0.57 \\
PD/AD & +0.07 & +0.01 & & +0.47 & +0.55 \\
\hline
\end{tabular}

Values represent correlation coefficient $(r)$. The correlation coefficients are derived from individual cases, so that the binding values for NMDA receptors were correlated with values for mazindol binding.

$* P<0.05$, one-way ANOVA.

had more ${ }^{3} \mathrm{H}$-mazindol-labeled DA transporter sites than the putamen $(p<0.05)$. Further examination of this difference showed that this effect was due to the marked loss of DA transporter sites in PD and PD/AD putamen $(p<0.05)$. The significant region effect was determined to result from greater ${ }^{3} \mathrm{H}$ mazindol binding in the ventral caudate and putamen than the dorsal regions of these structures $(p<0.05)$. This three-factor mixed ANOVA also indicated a significant diagnostic group $\times$ structure interactions $[F(3,20)=4.56, p<0.05]$. Tukey post hoc comparisons demonstrated that elderly controls had similar ${ }^{3} \mathrm{H}$-mazindol binding to DA transporter sites in the caudate and putamen, but patients diagnosed with $\mathrm{PD}, \mathrm{AD}$, or PD/AD had greater ${ }^{3} \mathrm{H}$-mazindol binding in the caudate than the putamen $(p<0.05)$.

In $\mathrm{PD}$, the reduction in ${ }^{3} \mathrm{H}$-mazindol binding reached: $79 \%$ in the dorsal caudate, $76 \%$ in the ventral caudate, $82 \%$ in both the dorsal and ventral putamen (all $p<0.05$ ). In PD/AD striatum, the decrease in ${ }^{3} \mathrm{H}$-mazindol binding was not as great as in $\mathrm{PD}$ striatum and reached $58 \%$ in the dorsal caudate, $52 \%$ in the ventral caudate, and $76 \%$ in both regions of putamen (all $p$ $<0.05)$. In $\mathrm{AD},{ }^{3} \mathrm{H}$-mazindol binding was significantly reduced only in the ventral putamen $(27 \%, p<0.05)$. A $24 \%$ decrease in the dorsal putamen and $14 \%$ elevation of ${ }^{3} \mathrm{H}$-mazindol binding in the dorsal and ventral caudate of $\mathrm{AD}$ patients did not reach statistical significance.

A singlc-factor ANOVA conducted on ${ }^{3} \mathrm{H}$-mazindol binding to the DA transporter sites in the NAc revealed a significant difference among the diagnostic groups $[F(3,14)=8.05, p<$ $0.002 ;$ ]. In comparison with controls, the binding was reduced by $72 \%$ in PD patients, $57 \%$ in PD/AD patients, and $20 \%$ in $\mathrm{AD}$ individuals (all $p<0.05$ ).

\section{Relationship between $N M D A$ receptors and $D A$ transporter sites}

A regression analysis was performed in order to determine the relationship between binding to NMDA receptors and extent of damage to dopaminergic nigrostriatal pathway in the putamen and caudate nucleus of control and diseased subjects.

As shown in Table 4, for elderly controls the only statistically significant correlation was that between binding to NMDA receptors and DA transporter sites in the dorsal putamen. In contrast, $\mathrm{L}-{ }^{3} \mathrm{H}$-glutamate binding to NMDA receptors was negatively correlated with ${ }^{3} \mathrm{H}$-mazindol binding in the putamen (dorsal and ventral) and dorsal caudate of PD patients, and no correlation was found between NMDA receptors and DA terminals in $\mathrm{AD}$ and $\mathrm{PD} / \mathrm{AD}$ striatum.

\section{Discussion}

The most striking finding of the present study is that idiopathic $\mathrm{PD}$, pure $\mathrm{AD}$, and mixed $\mathrm{PD} / \mathrm{AD}$ share some alterations in the glutamatergic and dopaminergic systems within the striatum and NAc. These changes were detected in binding to NMDA receptors and DA transporter sites, while binding to KA and AMPA receptors in all three diseases remained at control levels.

The elevation in binding to NMDA receptors in the striatum and NAc of AD patients was qualitatively similar to that found in PD despite the fact that the ${ }^{3} \mathrm{H}$-mazindol binding to $\mathrm{DA}$ transporter sites was only moderately decreased in the putamen and NAc of AD patients (as compared with PD and mixed PD/ $\mathrm{AD}$ individuals) and was not statistically different from control levels in the caudate. By contrast, in PD a large increase in binding to NMDA receptors in the striatum and NAc was accompanied by a substantial loss of striatal DA transporter sites. More severe loss of DA transporter sites in the putamen of PD patients than in the caudate is consistent with studies demonstrating that the loss of DA (Kish et al., 1988) or DA transporter (Niznik et al., 1991) in idiopathic PD is likewise greater in the putamen than caudate. Thus, putamen and, to a lesser degree, the NAc appear to be denervated of their dopaminergic inputs in all three diseases, whereas dopaminergic denervation of caudate was observed only in idiopathic PD and mixed PD/AD. As AD patients in our study showed no coexistent PD pathology, this finding remains somewhat in contrast to reports describing essentially preserved concentrations of DA in the putamen of AD patients (Reinikainen et al., 1988) and unchanged ${ }^{3} \mathrm{H}-\mathrm{ma}-$ zindol binding in the striatum of AD patients (Mizukawa et al., 1993).

Since, as revealed by a regression analysis, binding to NMDA receptors correlates with binding to DA transporter sites in $\mathrm{PD}$ cases, but not $A D$ individuals, one can suggest that in $P D$, but not in AD, the increase in NMDA receptor binding depends upon severity of decline in dopaminergic inputs and reflects disease progression. Therefore, the cause of elevated binding to NMDA receptors in AD and PD patients appears to be different. For example, in AD, a substantial loss or pathology of glutamatergic cortical ncurons, some of which give rise to the corticostriatal glutamatergic projection (Carter, 1982; Fonnum, 1984; Francis et al., 1993), may bring about upregulation of striatal postsynaptic NMDA receptors. Indeed, an increased $\mathrm{L}-{ }^{3} \mathrm{H}-$ glutamate binding, which positively correlates with the density of neurofibrillary tangles in the neocortex, has been observed in the caudate of AD patients (Pearce et al., 1984). Elevated ${ }^{\mathbf{L}}{ }^{3} \mathrm{H}$-glutamate binding has also been found in the striatum of hemidecorticated rats (Roberts et al., 1982), and more recently an upregulation of NMDA receptors has been reported for the striatum of animals with bilateral or unilateral lesions of corticostriatal glutamatergic projections (Samuel et al., 1990). Furthermore, since either lesion of the nigrostriatal dopaminergic neurons or lesions of the corticostriatal glutamatergic projections have been shown to increase the density of NMDA receptors in rat striatum (Samuel et al., 1990), it is also reasonable to assume that the increase in $\mathrm{L}^{-}{ }^{3} \mathrm{H}$-glutamate binding found in the striatum of mixed PD/AD individuals is related to both the decreased density of nigrostriatal DA terminals and diminished corticostriatal glutamatergic input. In $\mathrm{PD} / \mathrm{AD}$ patients, this is 
reflected in an intermediate level of dopaminergic transporter site loss in the striatum accompanied by a significant (but smaller than in $\mathrm{PD}$ and $\mathrm{AD}$ ) elevation of $\mathrm{L}^{-}{ }^{-} \mathrm{H}$-glutamate binding to NMDA receptors.

Thus, it appears that the elevation of binding to striatal NMDA receptors in all of these seemingly disparate diagnostic groups may be explained by cooperative glutamate-DA influences over the neuronal circuitry of the basal ganglia. In PD, the initial insult might be expected to occur in the form of reduced nigrostriatal DA activity. Diminished nigrostriatal activity would alter activity of pallidum and substantia nigra pars reticulata, resulting in diminished thalamic activity and cortical stimulation and finally, reduced corticostriatal activity. Diminished corticostriatal glutamatergic activation may, in turn, produce a compensatory NMDA receptor upregulation in the PD striatum. Conversely, the initial insult in AD might be expected to occur in the form of reduced corticostriatal glutamatergic input. In this situation, the reduced activation of striatal neurons would also interrupt the normal activity of the striato-pallido-thalamocortical loop. Such circuitry changes might also lead to damage of DA neurons in the substantia nigra as some degeneration in the substantia nigra in AD brains has been shown to occur (Ditter and Mirra, 1987), and recent studies provide evidence that long-standing lesions of the prefrontal cortex can elicit PDlike degenerative changes in the dopaminergic neurons of the substantia nigra and striatum (Mazurek and Kiriakopoulos, 1993).

If this loop is, indeed, responsible for the changes in NMDA receptors observed in the present study, then our findings further support the hypothesis that alterations in corticostriatal glutamatergic activity may affect the dopaminergic system of the basal ganglia and vice versa. Moreover, if the changes observed in the striatum of $\mathrm{AD}$ and $\mathrm{PD}$ patients do occur in response to an alteration in the same basal ganglia circuitry, the commonality between $\mathrm{AD}$ and PD should be less surprising. Thus, some of the extrapyramidal symptoms, primarily rigidity and hypokinesia reported in $\mathrm{AD}$ patients that usually develops later in the course of the disease, may result from the involvement of the basal ganglia circuitry. The dementia that sometimes accompanies PD might also be understood from this same perspective.

Limited tissue availability did not allow us to conclude whether the increase in binding to NMDA receptors in the striatum and $N A c$ of $P D, A D$, and $P D / A D$ individuals results from changes in the receptor density or receptor affinity. Animal studies suggest, however, that extensive degeneration of nigrostriatal dopaminergic terminals or loss of glutamatergic corticostriatal input may result in increased density of striatal NMDA receptors, without changes in their affinity (Samuel et al., 1990).

A substantial increase of binding to NMDA receptors observed in PD striatum in the present study confirms our previous observations (Weihmuller et al., 1992). It also is in accord with the report that binding to NMDA receptors in rat striatum is elevated by $42 \%$ 2-3 weeks after lesion of the nigrostriatal dopaminergic neurons with 6-OHDA (Samuel et al., 1990). On the other hand, our finding contrasts with observations of unchanged ${ }^{3} \mathrm{H}-\mathrm{MK}-801$ binding to ion channel-associated phencyclidine (PCP) sites of the NMDA receptor complex in the striatum of PD patients (Holemans et al., 1991), and of a $26 \%$ decline in binding to NMDA sites in the putamen of PD patients reported by Penney et al. (1992).

In the former study (Holemans et al., 1991) the DA concentration and tyrosine hydroxylase activity in PD striatum were less than $30 \%$ of control values similar to the loss of binding to DA transporter sites we have found. This suggests that the disparity in NMDA receptor findings in those two studies is due to factors other than the dopaminergic degeneration. For example, Holemans et al. (1991) performed binding of ${ }^{3} \mathrm{H}-\mathrm{MK}$ 801 to PCP receptors in the absence of exogenous glutamate and glycine, that is, in the conditions previously shown to be less optimal for detecting changes in binding to the NMDA receptor complex (Procter et al., 1989); therefore, it is possible that an increase in binding to the NMDA receptor complex could have been obscured. This point is especially pertinent since we have examined autoradiographically ${ }^{3} \mathrm{H}-\mathrm{MK}-801$ binding sites (in the presence of exogenous glutamate and glycine) in the striatum of a PD patient and a control, and found an increase in the ${ }^{3} \mathrm{H}-\mathrm{MK}-801$ binding in PD equivalent to that observed with $\mathrm{L}^{-3} \mathrm{H}$-glutamate as a ligand (data not shown). However, since ${ }^{3} \mathrm{H}-\mathrm{MK}-801$ binding in our study was performed on a single PD case, we cannot rule out the possibility that various recognition sites of the NMDA receptor complex are differently regulated in PD, similar to what has been previously observed in other pathological conditions (Pangalos et al., 1992; Ukas et al., 1992). In view of recent evidence that pharmacological diversity of NMDA receptors depends on the particular subunit composition (Buller et al., 1993), a conceivable diseaserelated switch in the NMDA receptor subunit composition could also contribute to dissimilar observations reported in studies using different ligands. Finally, it is also possible that differences pertaining to the level of striatal tissue taken for analysis in various studies (e.g., anterior striatum vs posterior striatum) may be another differentiating factor.

Our finding of a similar response of NMDA receptors in the striatum of $\mathrm{PD}, \mathrm{AD}$, and $\mathrm{PD} / \mathrm{AD}$ individuals, together with recently available tools enabling to evaluate the status of different subunits of the NMDA receptor (Monyer et al., 1992; Karp et al., 1993; Planells-Cases et al., 1993), may also prompt future studies on molecular mechanisms underlying that response, and possibly lead to the discovery of new treatment strategies.

\section{References}

Allard P, Alafuzoff I, Carlsson A, Eriksson K, Ericson E, Gottfries C-G, Marcusson JO (1990) Loss of dopamine uptake sites labeled with [ $\left.{ }^{3} \mathrm{H}\right]$ GBR-12935 in Alzheimer's disease. Eur Neurol 30:181-185.

Boller F, Mizutani T, Roessmann U, Gambetti P (1980) Parkinson disease, dementia, and Alzheimer disease: clinicopathological correlations. Ann Neurol 7:329-335.

Buller AL, Morrisett RA, Monaghan DT (1993) The NR2 subunit contributes to the pharmacological diversity of native NMDA receptors. Soc Neurosci Abstr 19:1356.

Carter CJ (1982) Topographical distribution of possible glutamatergic pathways from the frontal cortex to the striatum and substantia nigra in rats. Neuropharmacology 21:379-383.

Carter CJ, L'Hereux R, Scatton B (1988) Differential control by $N$-methyl-D-aspartate and kainate of striatal dopamine release in vivo: a trans-striatal dialysis study. J Neurochem 51:462-468.

Cheramy A, Romo R, Godehen G, Baruch P, Glowinski J (1986) In vivo presynaptic control of dopamine release in the cat caudate nucleus. II. Facilitatory or inhibitory influence of $\mathrm{L}$-glutamate. Neuroscience 19:1081-1090.

Clow DW, Jhamandas K (1989) Characterization of L-glutamate action on the release of endogenous dopamine from the rat caudateputamen. J Pharmacol Exp Ther 248:722-728.

Cowburn R, Hardy J, Roberts P, Briggs R (1988) Regional distribution of pre- and postsynaptic glutamatergic function in Alzheimer's disease. Brain Res 452:403-407.

Cowburn RF, Hardy JA, Briggs RS, Roberts PJ (1989) Characteris- 
ation, density, and distribution of kainate receptors in normal and Alzheimer's diseased human brain. J Neurochem 52:140-147.

Crowder JM, Bradford HF (1987) Inhibitory effects of noradrenaline and dopamine on calcium influx and neurotransmitter glutamate release in mammalian brain slices. Eur J Pharmacol 143:343-352.

Cummings JL (1986) Subcortical dementia. Neuropsychology, neuropsychiatry, and pathophysiology. Br J Psychiatry 149:682-697.

Desce JM, Godeheu G, Galli T, Artaud F, Cheramy A, Glowinski J (1991) Presynaptic facilitation of dopamine release through $D, L-\alpha-$ amino-3-hydroxy-5-methyl-4-isoxazole propionate receptors on synaptosomes from rat striatum. J Pharmacol Exp Ther 259:692-698.

Difazio MC, Hollingsworth Z, Young AB, Penney JB (1992) Glutamate receptors in the substantia nigra of Parkinson's disease brains. Neurology 42:402-406.

Ditter SM, Mirra SS (1987) Neuropathologic and clinical features of Parkinson's disease in Alzheimer's disease patients. Neurology 37: 754-760.

Fonnum F (1984) Glutamate: a neurotransmitter in mammalian hrain. J Neurochem 42:1-11.

Francis PT, Sims NR, Procter AW, Bowen DM (1993) Cortical pyramidal neurone loss may cause glutamatergic hypoactivity and cognitive impairment in Alzheimer's disease: investigative and therapeutic perspectives. J Neurochem 60:1589-1604.

Geddes JW, Ukas J, Brunner LC, Choe W, Cotman CW (1992) Hippocampal excitatory amino acid receptors in elderly, normal individuals and those with Alzheimer's disease: non- $N$-methyl-D-aspartate receptors. Neuroscience 50:23-34.

Hansen L, Salmon D, Galasko D, Masliah E, Katzman R, DeTeresa R, Thal L, Pay MM, Hofstetter R, Klauber M, Rice V, Butters N, Alford $M$ (1990) The Lewy body variant of Alzheimer's disease: a clinical and pathologic entity. Neurology 40:1-8.

Holemans S, Javoy F, Agid Y, Laterre EC, Maloteaux J-M (1991) $\left[{ }^{3} \mathrm{H}\right] \mathrm{MK}-801$ binding to NMDA glutamatergic receptors in Parkinson's disease and progressive supranuclear palsy. Brain Res 565:154 157 .

Hornykiewicz O (1973) Parkinson's disease: from brain homogenate to treatment. Fed Proc 32:183-190.

Jellinger K, Braak H, Braak E, Fischer P (1990) Alzheimer lesions in the entorhinal region and isocortex in Parkinson's and Alzheimer's diseases. Ann NY Acad Sci 640:203-209.

Karp SJ, Masu M, Eki T, Ozawa K, Nakanishi S (1993) Molecular cloning and chromosomal localization of the key subunit of the human $N$-methyl-D-aspartate receptor. J Biol Chem 268:3728-3733.

Khachaturian ZS (1985) Diagnosis of Alzheimer's disease. Arch Neurol 42:1097-1105.

Kish SJ, Shannak K, Hornykiewicz O (1988) Uneven pattern of dopamine loss in the striatum of patients with idiopathic Parkinson's disease. N Engl J Med 318:876-880.

Klockgether T, Turski L (1990) NMDA antagonists potentiate antiparkinsonian actions of $\mathrm{L}$-dopa in monoamine-depleted rats. Ann Neurol 28:539-546.

Klockgether T, Turski L, Honore T, Zhang Z, Gash DM, Kurlan R, Greenamyre JT (1991) The AMPA receptor antagonist NBQX has antiparkinsonian effects in monoamine-depleted rats and MPTP treated monkeys. Ann Neurol 30:717-723.

Krebs MO, Desce JM, Kemel ML, Gauchy C, Godeheu G, Cheramy A, Glowinski J (1991) Glutamatergic control of dopamine release in the rat striatum: evidence for presynaptic $N$-methyl-D-aspartate receptors on dopaminergic nerve terminals. J Neurochem 56:81-85.

Leverenz J, Sumi SM (1986) Parkinson's disease in patients with Alzheimer's disease. Arch Neurol 43:662-664.

Lustig HS, von B, Ahern K, Greenberg DA (1992) Antiparkinsonian drugs and in vitro excitotoxicity. Brain Res 597:148-150.

Mazurek MF, Kiriakopoulos ET (1993) Chronic cortical lesions produce Parkinson's disease-like changes in the substantia nigra of the rat. Soc. Neurosci Abstr 19:406.

Mitchell PR, Doggett NS (1980) Modulation of striatal [ $\left.{ }^{3} \mathrm{H}\right]$-glutamic acid release by dopaminergic drugs. Life Sci 26:2073-2081.

Mizukawa K, McGeer EG, McGeer PL (1993) Autoradiographic study on dopamine uptake sites and their correlation with dopamine levels and their striata from patients with Parkinson disease, Alzheimer disease, and neurologically normal controls. Mol Chem Neuropathol 18:133-144.

Molsa PK, Marttika RJ, Rinne UK (1984) Extrapyramidal signs in Alzheimer's disease. Neurology 34:1114-1116.

Monyer H, Sprengel R, Schocpfer R, Hcrb A, Higuchi M, Lomeli H, Burnashev N, Sakmann B, Seeburg PH (1992) Heteromeric NMDA receptors: molecular and functional distinction of subtypes. Science 256:1217-1221.

Mount H, Quirion R, Chaudieu I, Boksa P (1990) Stimulation of dopamine release from cultured rat mesencephalic cells by naturally occurring excitatory amino acids: involvement of both $N$-methyl-Daspartate (NMDA) and non-NMDA receptor subtypes. J Neurochem 55:268-275.

Nieoullon A, Cheramy A, Glowinski J (1978) Release of dopamine evoked by electrical stimulation of the motor and visual areas of the cerebral cortex in both caudate nuclei and in the substantia nigra in the cat. Brain Res 145:69-83.

Niznik HB, Fogel EF, Fassos FF, Seeman P (1991) The dopamine transporter is absent in parkinsonian putamen and reduced in the caudate nucleus. J Neurochem 56:192-198.

Olney JW, Price MT, Labruyere J, Salles KS, Frierdich G, Mueller M, Silverman E (1987) Anti-parkinsonian agents are phencyclidine agonists and $N$-methyl-D-aspartate antagonists. Eur J Pharmacol 142: 319-320.

Pangalos MN, Francis PT, Foster AC, Pearson RCA, Middlemiss DN, Bowen DM (1992) NMDA receptors assessed by autoradiography with $\left[{ }^{3} \mathrm{H}\right] \mathrm{L}-689,560$ are present but not enriched on corticofugalprojecting pyramidal neurones. Brain Res 596:223-230.

Pearce BR, Palmer AM, Bowen DM, Wilcock GK, Esiri MM, Davidson AN (1984) Neurotransmitter dysfunction and atrophy of the caudate nucleus in Alzheimer's disease. Neurochem Pathol 2:221-232.

Penney JB, Dure LS IV, Catania MV, Carlson M, Price RH, Hollingsworth Z, Young AB (1992) Benzodiazepine, glutamate, muscarinic and dopamine receptors in putamen and globus pallidus of Alzheimer's and Parkinson's diseases. Soc Neurosci Abstr 18:851.

Planells-Cases R, Sun W, Ferrer-Montiel AV, Montal M (1993) Molecular cloning, functional expression, and pharmacological characterization of an $N$-methyl-D-aspartate receptor subunit from human brain. Proc Natl Acad Sci USA 90:5057-5061.

Procter AW, Wong EHF, Stratmann GC, Lowe SL, Bowen DM (1989) Reduced glycine stimulation of $\left[{ }^{3} \mathrm{H}\right] \mathrm{MK}-801$ binding in Alzheimer's disease. J Neurochem 53:698-704.

Reinikainen KJ, Paljarvi L, Halonen T, Malminen O, Kosma V-M, Laakso M, Riekkinen PJ (1988) Dopaminergic system and monoamine oxidase-B activity in Alzheimer's disease. Neurobiol Aging 9:245-252.

Roberts PJ, McBean GJ, Sharif NA, Thomas EM (1982) Striatal glutamatergic function: modifications following specific lesions. Brain Res 235:83-91.

Samuel D, Errami M, Nieoullon A (1990) Localization of $N$-methylD-aspartate receptors in the rat striatum: effects of specific lesions on the $\left[{ }^{3} \mathrm{H}\right] 3$-(2-carboxypiperazin-4-yl)propyl-1-phosphonic acid binding. J Neurochem 54:1926-1933.

Simpson MDC, Royston MC, Deakin JFW, Cross AJ, Mann DMA, Slater $\mathbf{P}$ (1988) Regional changes in $\left[{ }^{3} \mathrm{H}\right] \mathrm{D}$-aspartate and $\left[{ }^{3} \mathrm{H} \mid \mathrm{TC} P\right.$ binding sites in Alzheimer's disease brains. Brain Res 462:76-82.

Ulas J, Brunner LC, Geddes JW, Choe W, Cotman CW (1992) $\mathrm{N}$ methyl-D-aspartate receptor complex in the hippocampus of elderly, normal individuals and those with Alzheimer's disease. Neuroscience $49: 45-61$.

Weihmuller FB, Ulas J, Nguyen L, Cotman CW, Marshall JF (1992) Elevated NMDA receptors in Parkinsonian striatum. Neuroreport 3:977-980.

Westerink BHC, Santiago M, De Vries JB (1992) The release of dopamine from nerve terminals and dendrites of nigrostriatal neurons induced by excitatory amino acids in the conscious rat. Naunyn Schmiedebergs Arch Pharmacol 345:523-529. 